\title{
Private Business' Roles as Stakeholders in Developing Surabaya as Tourism Destination
}

\author{
Agoes Tinus Lis Indrianto ${ }^{1 *}$, Kadir H. Din², Basri Rashid² \\ ${ }^{1}$ Hotel and Tourism Business, Faculty of Tourism, Ciputra University, Surabaya, Indonesia \\ ${ }^{2}$ School of Tourism, Hospitality and Event Management, College of Law, Government and International Study, Universiti \\ Utara Malaysia, Malaysia
}

\begin{abstract}
According to UNWTO report, the international tourist arrivals reached 1.2 billion people in 2016 . There was $5 \%$ growth in the developed countries and $2 \%$ growth in the developing countries, including Indonesia. In 2016, Indonesia welcomed 11.52 million international tourists. As the second biggest city in Indonesia, Surabaya has important roles for the country. Receiving around 564,000 international tourists in 2016, Surabaya had changed into a tourism destination. The development began in 2005 when Surabaya Tourism Promotion Board was set up to promote the city tourism. This board consists of private tourism business, such as hotels, restaurants, travel agents and tourist attraction operators. They are working together with other tourism stakeholders in Surabaya. This study aims to reveal the roles of private business in developing Surabaya as tourism destination. The study describes the activities done by private business to develop Surabaya, such as conducting promotional activities, developing products, initiating new programs and joining in international events. Moreover, they are actually helping their own business as well as supporting tourism destination development in Surabaya. This study shows that commitment, consistency, and collaboration among private business as the stakeholders are the keys to develop tourism destination in Surabaya.
\end{abstract}

Keywords: Destination, Development, Private Business, Roles, Surabaya, Tourism.

\section{INTRODUCTION}

Surabaya as the second biggest city in Indonesia has transformed into a metropolitan city. Located in the seaside area, this city becomes the center of trade for Eastern part of Indonesia [1]. This city has a dynamic development in regard to the commodity and the product of the city, from the colonial era until recently. For years, the main income of the city is mostly from manufacture and trade. However, Bureau of Statistics reports the city incomes had started to change in 2003, from trade and manufacture into trade and services [2]. This condition eventually brings tourism to be one of the important driving factors for service industry in Surabaya. The development of tourism in the city began to take place when the government set up Surabaya Tourism Promotion Board (STPB) in 2005 [3]. This board consists of tourism business people representing hotels, travels, and tourist attraction operators in Surabaya. Although it was set up by the government, this board was run and managed privately.

\footnotetext{
${ }^{*}$ Correspondence address:

Agoes Tinus Lis Indrianto

Email : agoes.tinus@ciputra.ac.id

Address : UC Town, Citraland, Made, Sambikerep, Surabaya, 60219.
}

The development of Surabaya as tourism destination was indicated by the use of city branding, Sparkling Surabaya in early 2006 [4]. The use of the branding had become the indicator of the effort to generate tourism activities in the city. As a tourism city, the character of Surabaya is different from the established tourism cities in Indonesia, such as Bandung in West Java, Yogyakarta in Central Java and Malang in East Java. Geographically, those cities are resort-based cities in which tourists mostly go there to have recreation with the family and do many leisure activities. On the other hand, visitors coming to Surabaya due to business activities, such as trade, meeting, convention, conference and exhibition [3]. Surabaya as a tourism city actually has many tourist attractions, thus developing urban tourist attractions becomes the concern of many stakeholders, especially for private business, such as hotels, travel agents and tourist attraction operators.

Creating more reasons for tourists to come and extend their length of stay in Surabaya become important objectives for tourism stakeholders. Surabaya is trying to become a tourism city, although it is not located in a resort area. The role of government as the stakeholder to attract tourists is highly needed. Unfortunately, after the launching of STPB in 
2005 and introducing Sparkling Surabaya as city branding, the effort of government is not as great as expected.

The number of local and international tourists in Surabaya keeps growing every year due to the effort of private business as well as local people. Moreover, the role of private business is crucial in developing tourism destination in Surabaya. Tourism stakeholder consists of hotels, restaurants, travel agents and tourist attraction operators, including tourism related business such as transportation and souvenirs store. This group of stakeholder has a high motivation to develop tourism activities, since the continuity of their business mostly depend on the tourists coming to Surabaya. Developing tourism in the area which is not geographically located in a tourism area, such as Surabaya, is challenging. There are still limited studies done on this subject. Therefore, this study aims to describe the roles of the private business in developing tourism destination in Surabaya. This qualitative study used interview, observation and literature review to collect the data. The data was described narratively in the study. The finding of this study had revealed the importance of private business as the stakeholder of tourism destination development, especially in the urban city which is not in a resort area, such as Surabaya.

\section{LITERATURE REVIEW}

Stakeholder in tourism is a topic that has been widely studied and explored by many researchers. The discussion about stakeholders had been going on for several years [5]. On the other hand, the tourism destination development is an ongoing process that has been widely studied both in the rural and urban tourism area. The process of the development is affected by many factors, in which tourism stakeholder plays important role in it. In order to frame the discussion, this chapter provides conceptual basis for this research. This chapter describes the definition and the concept of tourism stake-holders, especially private business as stake-holders in tourism destination development.

\section{Stakeholder Concept}

The initial definition of stakeholder is accredited to an internal memo produced in 1963 by the Stanford Research Institute [6]. According to this memo, stakeholder is a group of people who share the same objectives in the organization $[7,8]$. It is clear that this definition is completely organization-centered. Other definition elaborates stakeholder as any group or individual that can influence or be influenced by the accomplishment of the objectives which has been set by the group or individual in certain condition [9]. The later definition has been argued to have wider perspectives than the one earlier brought by the Stanford Research Institute. This definition may also create an opportunity for outside individuals or groups to consider themselves as stakeholders of an organization, without the acknowledgement of the organization. This definition stipulates both individuals and groups [10]. In this case, the definition is not only on the achievement of the objectives, but also focuses more on the relationship of the stakeholder. This also makes any group or individual can be included as stakeholders, since they are affected by unintentional consequences of the organization activities. In the context of tourism destination development, stakeholders can be individuals or groups who are directly and indirectly involve in the process, yet are affected by the process.

The most comprehensive definition of stakeholders suggests that stakeholders are those who make actual stakes and basically influence the organization [11]. Stakeholder is defined as any entity which affects or is affected by organizational performance, not only does this include living entities such as animals and plants, but also non-living environmental forms such as water and rocks. Furthermore, it also considers the former organizations or the elders as the stakeholders, since they are the ones who put the legacies. In the tourism destination development context, there are groups of people or individuals who have started the basics of development, but are no longer involved in the process of development.

\section{Definition of Tourism Stakeholder}

In tourism destination development, several stakeholders are actively involved in the process. Those stakeholders are from social, political and business elements. Stakeholders in tourism can be categorized into five parties, namely governments, private business, tourists, host communities and other related sectors [12]. Each of them has critical component for tourism destination development. The thoughts and initiatives of stakeholders are crucial for the strategic planning of the development process [13]. Nevertheless, the type of stakeholders in 
tourism may depend on the geographical location, issues and objectives [14,15].

In relation to private tourism business, the content of network relationships is associated with structure contributing to tourism business [16]. It is used to overcome shortage of resources and competencies among stakeholders.

\section{Private business as tourism stakeholder}

Along with the previous type of stakeholders [12], it is important to identify the groups or individual as the tourism stakeholder, especially private business. This study focuses on the network relation done by private tourism business to take part in the development process [17]. It includes generating needed ideas among private tourism business to cooperate effectively with other stakeholders. In line with business, tourism stakeholders comprise hotels, travel agents, restaurants, tourist attraction operators and other related business. The main responsibilities of the private business are accommodation (hotels and apartments), food and beverages (cafes and restaurants), shopping and entertainment (shopping centers, cinemas, and theme parks), Meeting Incentive Conference and Exhibition (MICE) business and other related services business [18]. Private business makes a living from providing services for tourists. Therefore, private business has to go beyond their boundaries to work with each other. Private business, especially small business scale, need to work together to achieve the maximum profit in their business [19]. Collaboration is crucial for small businesses which are typically associated with a shortage of funds and lack of management and marketing skills. However, bigger companies also need to cooperate and create network to obtain greater objectives. Stakeholders of tourism include those who are working under partnership of local management and other public organizations since they have direct activities on resource portion and tourism business related sectors [20].

\section{Tourism Destination Development}

Studies about the role of stakeholders in tourism destination development are viewed from various perspectives. The perspective of marketing is one of the most important factors for tourism destination development [21]. The publications in 1989 point out that the role of stakeholders in promoting the destination is an important part of the development [21]. Marketing has powerful influence for tourism destination development $[22,23]$. All of them put tourism destination development as the main discussion of their study. Tourism destination development needs an integrated marketing strategy that should be performed consistently. Developing tourism destination needs a great deal of planning and management initiatives $[24,25]$. It also involves all stakeholders who have direct relation with the tourism destination development.

The progress of tourism destination development can be seen through several indicators, such as economic, environmental and social development. The economic indicators are indicated by the growth of the amount of business [26], the establishment of the infrastructure and the increase of market. In terms of environmental and socio-cultural impacts, tourism destination development leads to the sustainability of the environment and the growing number of local culture conservation $[27,28]$. Furthermore, the tourism destination development involves certain phases that have different condition in every stage [26]. Several studies are conducted using Butler's Life Cycle to measure or explain the condition of [29]. Each of these researches has provided the basis for obtaining relevant information on tourism destination development aspects. The topic of tourism destination development is discussed using a multidisciplinary approach [30]. Understanding the overall change of tourism destination development is important, as tourism is a complex multi-element phenomenon. Thus, the outcome is mostly in interdisciplinary approach [31]. It creates the opportunities to understand tourism destination development in many perspectives.

\section{MATERIALS AND METHOD Data Collection}

This is a qualitative descriptive study, in which the primary data is gathered through indepth interview, observation and literature review. The primary data of this study was collected through in- depth interview with the informants and observation of activities. Five informants as important informants were being interviewed within 30-60 minutes duration. These informants represented the private business as the stakeholder of tourism destination development in Surabaya, which were: 1. the Head of STPB (Surabaya Tourism Promotion Board), 2. the Vice Chairperson of Casa Grande (Hotel General Manager Association), 3. the Head of House of Sampoerna 
Museum, 4. the Head of Aneka Kartika Travel Agent (the biggest inbound Tour Operator in Surabaya), and 5. the Head of FORKOM (Tourism Object Communication Forum).

For the primary data, this study applied the semi structured in depth interview. The interviews were conducted in the informant's offices with informal setting, which was elaborated according to the interview questions [32]. Thus, the analysis of the interviews was done through the interview transcripts. In addition, the observation was conducted during the events and the activities held by private business. Moreover, for the secondary data, this study applied literature review, which was obtained by reviewing the related literature on the subjects. This included gathering any publications related to activities of developing tourism in Surabaya, especially done by STPB, hotels, travel agents and tourism attraction operators.

\section{Data Analysis}

The data was summarized and sorted based on the subjects, and thematic framework approach was utilized for the data set [33]. Thus, the data collected from interview and observation was compared and contrasted to build the arguments for this study. The result was presented descriptively to explain and analyze the study's objectives.

\section{RESULT AND DISCUSSION}

Various type of private business becomes the stakeholders in tourism destination development in Surabaya. The existence of hotels, tour and travel companies, tourist attractions and restaurants become the dominant factors for attracting tourists. In addition, souvenirs shop, authentic local cake shop, and transportation are also important for tourism development process. All these private business are collaborating in order to develop Surabaya as an attractive tourist destination.

Additionally, they are not only working independently but also joining with others to develop Surabaya. There are several tourism organization such as PHRI (Association of Indonesia Hotel and Restaurant), ASITA (Association of Indonesia Tour and Travel Agency) and FORKOM (Communication Forum of Surabaya Tourist Object). These organizations collaborate to make Surabaya known not only locally but also internationally.

The effort of private business is crucial in developing Surabaya [3]. Surabaya tourism development began in 2005 when a tourism promotion board, called STPB (Surabaya Tourism Promotion Board) was launched, followed by the launching of the city branding Sparkling Surabaya, as seen in Figure 1 [34]. Though the initiation of this board was from the government, the ones managing the board were the private business. STPB consisted of tourism professionals and experts from various tourism businesses, who hold important position in their company and organization.

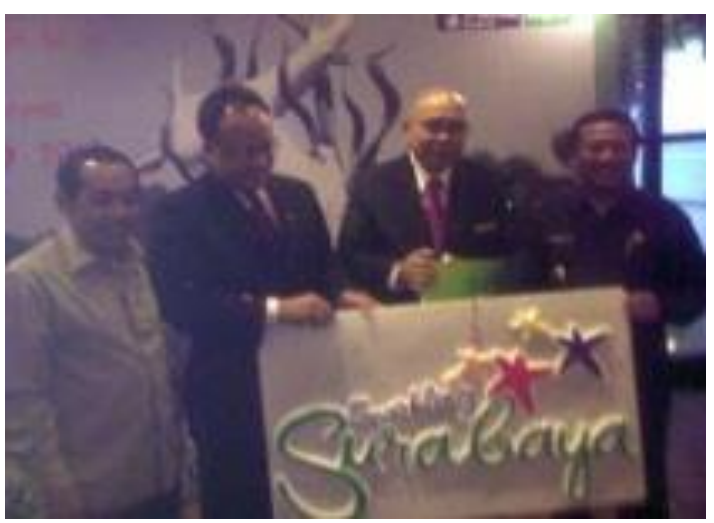

Figure 1. The Launching of Sparkling Surabaya

For years, STPB becomes the planner as well as the executer of all promotional activities to attract more tourists. In the past 10 years, there was a growing number in the tourists' arrival in Surabaya. The government official stated that in 2015, Surabaya welcomed 9,606,838 local tourists and 575,266 international tourists. Although the number of tourists was growing, unfortunately, the activities of STPB have been drastically declined in the past 5 years due to the lack of support from the government.

However, private business in Surabaya has shown its resilience, consistency and commitment in developing the city to be tourism destination. As the stakeholders, they work together in their own ways to maintain and boost tourism destination development in Surabaya. The collaboration among the stakeholders can be effectively applied to resolve and minimize the conflict as well as achieve the common goals [35]. The plans, strategies and activities of private business as tourism stakeholders are discussed further in the following section.

\section{Product Development}

In order to develop Surabaya as tourism destination, several private businesses have to create new products to attract tourists and accommodate their need during their stays in Surabaya. Tourism products should be created 
dynamically as part of the marketing strategy. It means that the products should be able to adapt to the need of the customers [36]. There are various forms of products and services that have been planned and developed by private business in Surabaya, such as tour package, room and meeting package, culinary products for souvenirs and new tourist attractions in the city, such as Suroboyo Night Carnival and Surabaya Heritage Track.

In regard to tour package, House of Sampoerna is one of the private companies managing a museum, art gallery and restaurant as its main attraction for tourists. This company later on organizes a free city tour using a trammodified bus to take the tourists sightseeing the city, as seen in the following figure [37].

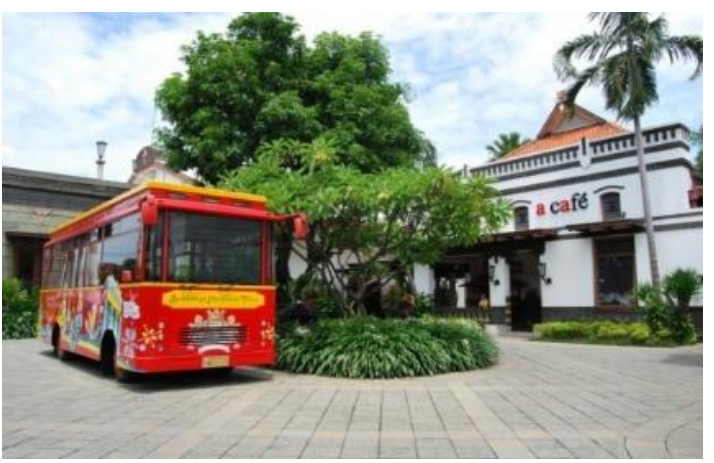

Figure 2. Surabaya Heritage Track

This free bus is called "Surabaya Heritage Track" or SHT since it only goes around the north and central Surabaya, where there are many heritage buildings around [1]. This bus becomes famous in Surabaya, since more tourists are eager to hop on the bus to have the city tour.

Furthermore, accommodation business should offer more services to their guests to make them feel more comfortable during their stays in Surabaya. One example is increasing the services level by not only selling the rooms, but also offerings their place as a venue for conducting many occasion. Many hotels in Surabaya have offered an interesting meeting package for their guests, especially business people. They combine room package with their meeting area in the hotel. Surabaya is also well known as the city of MICE (Meeting Incentive Conference and Exhibition), since there are plenty of venues to hold the small to large scale events. Those offers launched by hotels in Surabaya increase the awareness and the attention from visitors to conduct their event especially business event in Surabaya.
The tourist attraction operators as one of the important stakeholders in Surabaya tourism also actively develop new attractions for tourists. As stated by the head of FORKOM (Communication Forum of Tourism Object), recently there are around 50 tourism attractions operating in Surabaya and more than half of the members are private business managed by companies and local people. Several companies consistently launch new products to attract tourists. One of the most unique tourism products called the Artama Cruise is launched by Pelindo 3. Using a small and luxurious boat, the tourists can enjoy the view of the sea. As seen in figure 3 , the cruise takes only 2-3 hours cruising along the Madura Strait with Suramadu Bridge and the sunset as their main view [38].

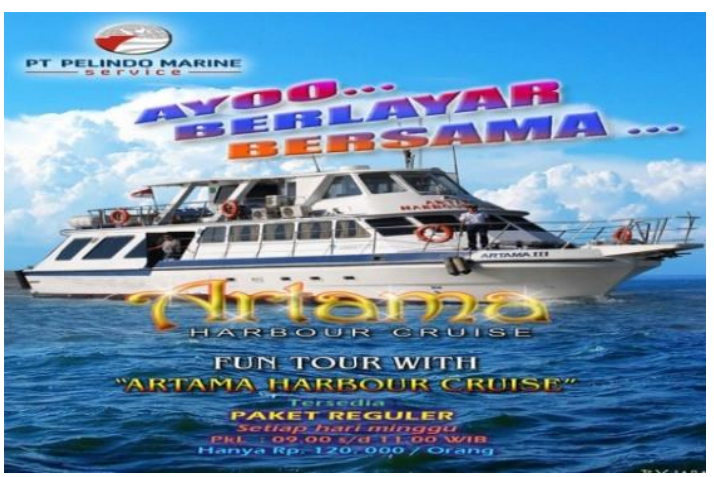

Figure 3. Artama Cruise

Besides creating tour activities, developing attractions, and providing accommodation, several private businesses in Surabaya are also producing culinary products as the souvenirs from Surabaya. The products are in the forms of snack, cookies and cake using Surabaya labels. They are claimed to be the authentic food created to serve the need of Surabaya tourists when they are going back home. The cake such as Kue Lapis Surabaya, Surabaya Patata and Almond Crispy Surabaya are actually not a local traditional cuisine of Surabaya. However, their existence and their effort of promoting the products have completed Surabaya as tourist city, since many tourists are eager to buy them as souvenirs for their family and relatives back home. The culinary experience is an important part of developing destination, since it creates memory and impression of the tourists [39].

\section{Promotional Activities}

All the private businesses dealing with tourism in Surabaya have actively tried to promote Surabaya as tourism destination. Each of the companies makes promotional effort 
online and offline to attract tourists. There are several offline activities that have been done to promote Surabaya, such as show, familiarization trip and advertising. Started in 2005, the activities to promote the city as tourism destination were basically in the hand of private business, under the coordination of Surabaya Tourism Promotion Board. The board which consists of the representative of hotels, restaurants, tourist attraction operators, tours and travels were setting up the plan as well as executed the promotional activities of the city.

In promoting the destination, it is important to attract a group of visitors to do tour activities or business trip (MICE) [40]. These two programs involved several parties to work together, such as hotels, travels and the media as the stakeholders. Road show program is a program in which a group of representative goes to other cities in Indonesia and overseas to promote Surabaya tourism. Mostly, they choose the city that has a direct flight to and from Surabaya. Thus, during the road show, the promotional team presents the potentials of Surabaya tourism to the invited guest. This activity is done to increase people awareness about Surabaya as tourism destination. The objectives of the activities are to promote Surabaya to the local tours and travels and to endorse the media to write about Surabaya. The road show is conducted regularly in several big cities in Indonesia, such as Jakarta, Bandung, Makassar, Semarang, Batam and Denpasar. While overseas road show are held in Kuala Lumpur, Manila, Brunei Darussalam and Singapore. The schedule is based on the availability of the assigned team and local invitees of the designated cities.

Furthermore, as a follow-up to the road show program, the tourism private business usually conducts the familiarization trip to promote Surabaya. In the familiarization trip process, firstly STPB invites several travel agents and media from other cities that has a direct flight to and from Surabaya. Then, the board forms a committee consisting of hotels, tours and travels, tourist attraction operators and restaurants to host the invited guests in Surabaya. The duration of the trip is mostly not more than 3 days, depends on the home city of the guests. The trip will last more than 3 days for overseas guests. The purpose of the familiarization trip is to build the experience of visiting Surabaya to the guests. By joining the trip, the invited guests can create business networking and share their experience to other people in their home origin. Moreover, the invited guests from media are expected to write about Surabaya and publish their writing in their home city to make people there to be informed about Surabaya and eager to visit the city. This activities are done twice a year depends on the schedule set up by board in conjunction with the overseas partners. Improving tourists experience in tourism destination is an important part of developing the destination [41]. It should be done collectively by all the stakeholders involved in the development.

Furthermore, another important promotional activity to develop Surabaya as tourism destination is offline advertising. In this regards, advertising is a part of promotion strategy commonly used by private business. In order to promote Surabaya tourism, several private businesses employ several tools such as leaflet, brochures and billboard. Leaflets and brochures are mostly used to sell their own particular products. Their specific brochures complete the brochures already made by the government. In creating advertising materials, several private businesses have worked together and shared the budget to produce the material. A city may practice cooperative advertising with several business entities to attract more tourists [42]. Besides producing brochures and leaflets, private business in Surabaya also utilize billboard as the media of advertisement. However, since it is considered as an expensive tool, the number of billboard promotion is limited in promoting Surabaya tourism. Most billboards are used to promote their own business. Besides offline advertising, private business in Surabaya also creates an online promotion. In most online promotion, private businesses are not only selling their own products and services, but also promoting Surabaya as tourism destination. Private business in Surabaya is very active in online promotion through website and social media to attract tourists.

\section{Program Initiation}

Private business are also working together to initiate several programs in attracting tourists to Surabaya. Those initiations are expected to attract more tourists to visit Surabaya. The programs are varied based on the core business of the company. Private business as the stakeholder creates programs that can promote Surabaya as well as increase their sales. Sales are the most important factor in marketing the tourism destination [23]. There are several program areas, such as retail, health and cultural 
events. Those programs are scheduled in different time of the year, combining with the ones conducted by the government, as seen in the following figure.

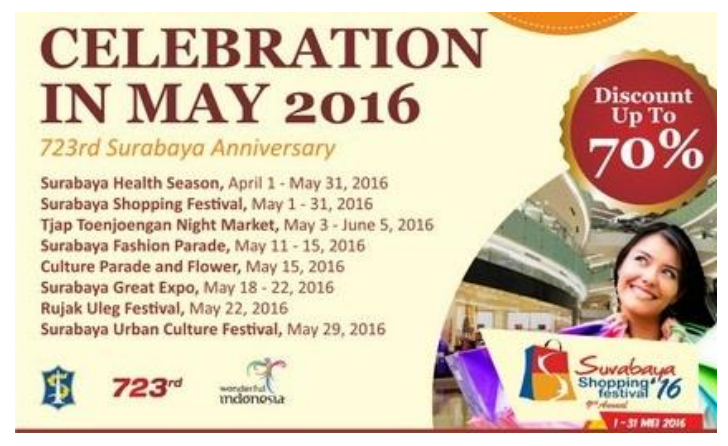

Figure 4. Surabaya Tourism Calendar of Events

The most significant program initiated by private business is the establishment of Surabaya Big Sale or nowadays called Surabaya Shopping Festival. Shopping tourism is becoming important in modern world [43]. In Surabaya Shopping Festival event, many private businesses join the program to offer discount on their products in order to elevate the image of Surabaya as a shopping destination. Most hotels, restaurants and travel agents are also participated in this event. Surabaya Shopping Festival program is initially proposed by hotels in Surabaya in order to give the visitors more reasons to come to Surabaya.

Another event initiated by groups of hotels is Surabaya Health Seasons programs. Groups of hotels, working together with the selected hospitals in Surabaya, initiated this program in 2010. The programs are still running and has been put as one of the routine agendas in Surabaya tourism events until now. Health tourism is increasing over the years and the use of website to promote hospitals or other related health services for the tourism destination development is important [44]. The objective of the program is to promote Surabaya as health tourism destination, especially for the people around Surabaya. This program showcases the capacity of the hospitals and other related health services business in Surabaya. Instead of going out of town or even going overseas, people are expected to stay in Surabaya for medical treatment. Surabaya Health Season or so called SHS program is a part of private business initiatives that have been well accepted by the people and the government of Surabaya.

Private business in Surabaya also initiates several cultural programs to make Surabaya as tourism destination. Among those cultural programs, the most prominent one is Surabaya Traffic Festival conducted by Suara Surabaya Media. This company is the best radio in Surabaya due to the number of active listeners. The program features many jazz musicians in several days. It was initially set up in 2011 and still existed until now. Jazz music festival has a wide variety of audiences, from younger to older generation. Besides, it can attract sponsors for the events as well [45]. The festival can directly give impact to the tourism destination, since it brings jazz lovers from outside the city to come and stay to enjoy the festival. This musical event become one of the iconic events of Surabaya, and has also been included as the city annual agenda. The program involves hotels, travel agents, and other tourism related business to cater the need of the tourists during the event. The satisfied music festival lovers in the event can create positive impression toward the location as well as increase the city expenditure, especially during the festival [46]. This program has made Surabaya to be more than just a business city. People also come to Surabaya for the music festival.

\section{Event Participation}

The role of private business in developing Surabaya as tourism destination is also seen in the active participation of the hotels, travel agents and tourist attraction operators on events conducted by the government either inside or outside Surabaya. Private business always support the programs held by the government as the effort to promote tourism in Surabaya. Several private businesses, especially travel agents and hotels, also actively participate on the international event to promote their products and Surabaya. They also join several international tourism events, such as ITB Berlin and ITB Asia in Singapore. Their participation in international event without getting special incentives from the government show the great commitment and contribution of private business toward tourism development in Indonesia, especially Surabaya. Joining the events is not only useful to promote their own business, but their presence also represents the city. Participation on the tourism events is important to draw attention to Surabaya for the prospective tourists. Therefore, during the travel fair, the intense time may create distinguished quality of the products for the consumers [47]. That is the reason why travel 
fair has significant impact on advertising the tourism destination.

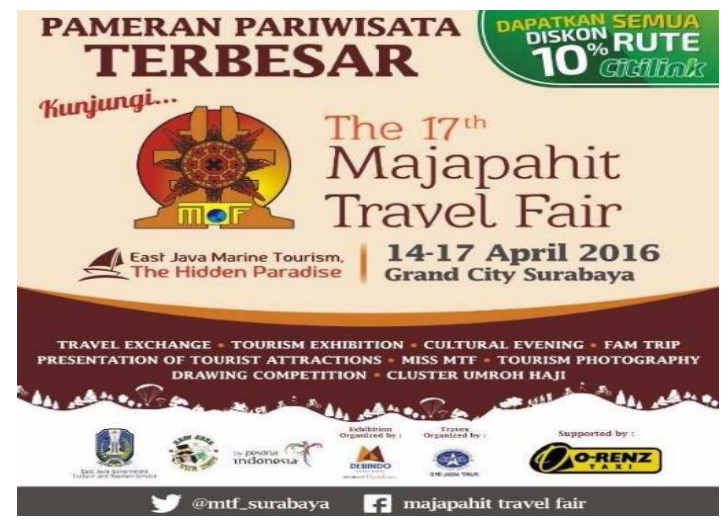

Figure 5. Majapahit Travel Fair Supported by Private Business in Surabaya

Besides becoming the participant on the event held by other countries, Surabaya has an annual travel fair agenda called Majapahit Travel Fair [48]. Though the organizer is the Provincial Government of East Java, the participants and the supporters are mostly from private business located in Surabaya. Those who have tourism and hospitality services as their core business are the ones who are actively involved in this occasion, which is usually held around April May every year. In 2016, there were around 118 buyers from 16 countries who came to Majapahit Travel Fair to meet merchants from Indonesia, especially Surabaya. Majapahit Travel Fair is the biggest travel fair in Eastern part of Indonesia which is supported fully by hotels and travel agents in Surabaya, from the preparation until execution phases. As the stakeholder of tourism, everybody gets involved in the process of the travel fair. The role of private business seems to be dominant in the process, since their participations are one of the success factor keys of the event.

Furthermore, the role of private business as stakeholder in tourism destination development in Surabaya is also seen from their support toward the government agenda. In 2016, Surabaya was hosting several global events. The major international event in Surabaya was Preparatory Committee (Prep Comm) 3 Habitat, by United Nation Event. At this occasion, Surabaya was visited by more than 4.400 guests from 167 countries at the same time [49]. The readiness of the accommodation, food, transportation and attraction providers to serve the guests had proven the ability and the capacity of private tourism business in Surabaya.
This event was considered successful and had officially put Surabaya as one of International MICE cities in the region. The government as the host would not be successful without the full support from private business in Surabaya. In this event, private business accommodated the need of visitors, as they also aimed to gain business profit. However, their active roles in supporting the city agenda are also making the destination become more attractive and reliable for tourists, especially in accommodation, attraction and transportation facilities. The consistency of support and the commitment from private business are the key factors to develop Surabaya as tourism destination.

\section{CONCLUSION}

Private businesses consisting of hotels, travel agents, restaurants and tourist attraction operators have an important role to develop the tourism destination. The role of private business in developing tourism destination in Surabaya is reflected in the ways hotels, travels agents, restaurants and tourist attraction operators working together to attract and host tourists. Private businesses in Surabaya have been very active in developing new products in their services, such as launching free bus for city tour in the heritage areas and operating sunset dinner cruise along Madura strait. The effort of private business is also shown through their initiatives in setting up several programs that can attract more tourists. The launch of Surabaya Great Sale in 2006, which later became Surabaya Shopping Festival in 2008 until recent years, had contributed great revenues to the city directly and indirectly. Thus, the launching of Surabaya Health Season in 2010 to promote health tourism in Surabaya had shown that the city was developing in many ways to become a tourism destination. The music festival called The Jazz Traffic which was started in 2011 had completed Surabaya as an urban tourism destination in Indonesia.

Working together to develop tourism destination among private business in Surabaya has been done in the formal setting as well as informal one. Tourism destination development in Surabaya succeeds because of the strong commitment of private business in working together to promote the city. In certain occasion, the private businesses are serving not only as actor but also the director of the tourism development in Surabaya. Consistent collaboration and strong commitments are the 
keys for private business to support tourism destination development.

\section{REFERENCES}

[1] Handinoto. 1996. Perkembangan kota dan arsitektur Kolonial Belanda di Surabaya 1870-1940. UK Petra and Andi. Yogyakarta.

[2] Surabaya Tourism Statistic. 2016. Statistic Center. Available at: surabaya.bps.go.id.

[3] Anshory, Y. and D. G. Satrya. 2008. Sparkling Surabaya: pariwisata dengan huruf L. Bayu Media Publishing. Malang.

[4] Puspita, L. 2008. Transformasi identitas kota surabaya dalam Sparkling Surabaya sebagai branding kota. Master Thesis. Department of Communication, Airlangga University, Surabaya.

[5] Nogueira, S. and J. C. Pinho. 2015. Stakeholder network integrated analysis: the specific case of rural tourism in the Portuguese Peneda-Geres National Park International Journal of Tourism Research 17, 325-336.

[6] Freeman, R. E. 1984. Strategic management: a stakeholder approach. Pitman. Boston.

[7] Freeman, R. and D. Reed. 1983. Stockholders and stakeholders: a new perspective on corporate governance. California Management Review 25, 88-106.

[8] Bowie, N. E. 1988. The moral obligations of multinational corporations'. In: Luper-Foy, S. (Ed). Problems of International Justice. Westview Press. Boulder, CO. 97-113.

[9] Freeman, R. E., J. S. Harrison and A. C. Wicks. 2007. Managing for stakeholders: survival, reputation, and success. Yale University Press. New Haven.

[10] Gray, R., D. Owen and C. Adams. 1996. Accounting and Accountability: Changes and challenges in corporate social and environmental reporting. Prentice-Hall. Hemel Hempstead.

[11] Starik, M. 1994. Reflections on stakeholder theory. Business and Socity 33(1), 82-131.

[12] Swarbrooke, J. 2001. Sustainable tourism management, $2^{\text {nd }} E d$. $C A B$ International. London.

[13] Dill, W. R. 1975. Public participation in corporate planning - Strategic management in a Kibitzer's World. Long Range Planning 8(1), 57-63.

[14] Timur, S. and D. Getz. 2008. A network perspective on managing stakeholders for sustainable urban tourism. International
Journal of Contemporary Hospitality Management 20(4), 445-461.

[15] Cooper, C., N. Scott and R. Baggio. 2009. Network position and perceptions of destination stakeholder importance. Anatolia 20(1), 33-45.

[16] O'Donnell, A., A. Gilmore, D. Cummings and D. Carson. 2001. The network construct in entrepreneurship research: a review and critique. Management Decision 39(9), 749760.

[17] Borgati, S. P. and P. C. Foster. 2003. The network paradigm in organizational research: a review and typology. Journal of Management 29(6), 991-1013.

[18] Anuar, A. N. A, H. Ahmad, H. Jusoh and M. Y. Hussain. 2012. Understanding the role of stakeholder in the formation of tourist friendly destination concept. Journal of Management and Sustainability 2(2), 69-74.

[19] Morrison, A. and R. Thomas. 1999. The Future of small firms in the hospitality industry. International Journal of Contemporary Hospitality Management 11(4), 148154.

[20] Bramwell, B. and A. Sharman. 1999. Collaboration in local tourism policy making. Annals of Tourism Research 26(2), 392-415.

[21] King, B. and G. Hyde. 1989. Tourism marketing in Australia. Hospitality Press. Melbourne.

[22] Kotler, P., J. Bowen and J. Makens. 1999. Marketing for hospitality and tourism, $2^{\text {nd }}$ Ed. Prentice-Hall. New Jersey.

[23] Johnson, D. 2000. Sales and marketing in the tourism industry. McGraw-Hill Companies. Sydney.

[24] Pearce, P. 1989. Fundamentals of tourist motivation. In: Pearce, D. and R. W. Butler (Eds). Tourism Research: Critiques and Challenges. Routledge. London. 113-134.

[25] Hall, C. 1991. Introduction to tourism in Australia: impacts, planning and development. Longman Cheshire Pty Ltd. Melbourne, VIC.

[26] Butler, R. 2006. The future and the TALC. In: Butler, R. (Ed). The tourism Area Life Cycle Vol. 2: Conceptual and Theoretical Issues Channel View Publications. London. 281290.

[27] Craik, J. 1991. Resorting to tourism: cultural policies for tourist development in Australia. Allen and Unwin. Sydney. 
[28] Carter, R. and R. J. S. Beeton. 2004. A model of cultural change and tourism. Asia Pacific Journal of Tourism Research 9(4), 423-442.

[29] Williams, P. and A. Gill. 1999. A workable alternative to the concept of carrying capacity: growth management planning. In: Singh, V. and S. Singh (Eds). A Workable Alternative to the Concept of Carrying Capacity: Growth Management Planning Cognizant Communication Corporation. New York. 51-64.

[30] Oh, H., B. Y. Kim and J. H. Shin. 2004. Hospitality and tourism marketing: recent developments in research and future directions. International Journal of Hospitality Management 23(5), 425-447.

[31] Carlsen, J. 1999. A systems approach to island tourism destination management. Systems Research and Behavioral Science 16(4), 321-328.

[32] Ruhanen, L. 2006. Moving beyond the theory: stakeholder perspectives of sustainable tourism. Paper presented at the Cutting Edge Research in Tourism - New Directions, Challenges and Applications. University of Surrey. Guildford.

[33] Berg, B. L. 2004. Qualitative research methods for the social sciences, $5^{\text {th }}$ Ed. Pearson. Boston.

[34] Detiknews.com. 2017. Sparkling Surabaya launching. Available at: https://id.pinterest .com/pin/669980882037146611.

[35] Gray, B. 1989. Collaborating: finding common ground for multiparty problems. Joss Bass. San Francisco.

[36] Walker, R. and M. K. Enjet. 1998. Dynamics of marketing a tourism destination: the Tasmanian Experience. In: Lovelock, H. C., P. G. Patterson and R. H. Walker (Eds). Services Marketing: Australia and New Zealand. Prentice Hall. Sydney. 530-553.

[37] Goodnews from Indonesia. 2017. Menjajal City Tour ala Indonesia. Available at: https://www.goodnewsfromindonesia.id/2 017/01/06/menjajal-city-tour-bus-alaindonesia.

[38] Pelindomarine. 2017. Artama Cruise. Available at: http://wisata.pelindomarine. com/p/paket-regular-artama-cruise.html.

[39] Tong, F. X., Y. K. D. Tong and S. W. Tam. 2016. Food tourism: the Melaka gastronomic experience. Journal of
Emerging Trends in Marketing and Management 1(1), 236-246.

[40] Line, N. D. and Y. Wang. 2015. Marketoriented destination marketing: an operationalization. Journal of Travel Research, 56(1), 122-135.

[41] Gopalan, R. and B. Narayan. 2010. Improving customer experience in tourism: a framework for stakeholder collaboration. Socio-Economic Planning Sciences 44, 100112.

[42] Mckinney, B. W., F. M. Hazeldine and K. S. Chawla. 2009. An analysis of the effects of cooperative advertising on tourism. Tourism Analysis 14, 573-586.

[43] Zaidan, A, E. 2016. Tourism shopping and new urban entertainment: a case study of Dubai. Journal of Vacation Marketing 22(1), 29-41.

[44] Mason, A. and K. B. Wright. 2011. Framing medical tourism: an examination of appeal, risk, convalescence, accreditation, and interactivity in medical tourism web sites. Journal of Health Communication 16(2), 163-177.

[45] Oakes, S. 2010. Profiling the jazz festival audience. International Journal of Event and Festival Management 1(2), 110-119.

[46] Andersson, D. T., J. Armbrecht and E. Lundberg. 2015. Linking event quality to economic impact a study of quality, satisfaction, use value and expenditure at a music festival. Journal of Vacation Marketing 23(2), 114-132.

[47] Lim, C. 2013. Analysis of time pressure and value perception: an explanatory study of consumer travel fair. Journal of Travel and Tourism Marketing 30, 509-521.

[48] Tribunnews. 2017. Majapahit Travel Fair 2017 datangkan ratusan buyers mancanegara. Available at: http://www. tribunnews.com/travel/2017/02/24/majap ahit-travel-fair-2017-datangkan-ratusanbuyers-mancanegara.

[49] Syafauziah, S. J. 2016. Jusuf Kalla buka The Third Preparatory Committee United Nations for Habitat di Surabaya. Available at: https://nasional.tempo.co/read/news/ 2016/07/25/058790155/jusuf-kalla-bukathe-third-preparatory-committee-unitednations-for-habitat-di-surabaya. 